COBISS: 1.01

\title{
SUBCUTANEOUS ROCK FORMS
}

\author{
PODTALNE SKALNE OBLIKE
}

\author{
TADEJ SLABE ${ }^{1}$
}

${ }^{1}$ Karst Research Institute, Scientific Research Centre of Slovenian Academy of Sciences and Arts, SI-6230 POSTOJNA, SLOVENIA

Prejeto / received: 15. 7. 1999 


\section{Tadej Slabe: Podtalne skalne oblike}

Na kraškem površju, ki je pokrito z naplavino ali prstjo, nastajajo tudi podtalne skalne oblike. So posledica pretakanja vode po stiku med skalo in prstjo, prenikanja vodo skozi prst in pritekanja vode do površine prsti, ki obdaja skalo. Podtalne skalne oblike so pogosto pomembna sled razvoja kraškega površja. To je poskus razločevanja tipičnih kraških podtalnih skalnih oblik in zasnova za njihovo novo tipizacijo.

Ključne besede: podtalne skalne oblike, kraški skalni relief, kraško površje.

\section{Abstract}

UDC: $551.435 .1: 551.44$

\section{Tadej Slabe: Subcutaneous rock forms}

Subcutaneous rock forms occur on karst surfaces covered with sediment or soil. They are the consequence of water running along the contact between rock and soil, the percolation of water through the soil, and inflow of water to the surface of the soil surrounding the rock. Subcutaneous rock forms are often important traces of the development of karst surfaces. This article tries to distinguish typical karst subcutaneous rock features and to offer a design for their new standardization.

Key words: subcutaneous rock forms, karst rock relief, karst surface. 


\section{INTRODUCTION}

Unique rock forms occur at the contact between fine-grained sediment or soil and carbonate rock, both on karst surfaces and in caves. A small amount of water flows along the contact between them and forms various channels and subcutaneous scallops, and when the water percolates through the soil or through the rock in contact with it, recesses and channels occur. At the level of the soil, notches and half-bells form. As a rule, the cross-sections of such rock forms are semicircular and rounded and their surfaces on homogeneous and non-fractured rock are commonly smooth.

Rock forms are shapes in the rock. The rock relief joining them is the form of the surface of the rock or karst caves. Rock forms are an important trace of the factors which shaped the rock. The traces of many different factors that operated simultaneously are often interwoven on the rock, or they are arranged according to various development periods and newer traces more or less effectively cover older traces. I distinguish rock forms from karst forms, either karren or dolines, which can also be covered with soil. Karst forms are due to water percolation through fissured or porous rock while rock forms are due to various factors acting on the surface of the rock. Rock forms are a constituent part of the surface of karst features. Rock features occur on non-carbonate rocks also this is why one may add the adjective "karst" to the rock features appearing on karst to allow better differentiation with other rock forms. Rock cavities (Gams 1971, 29; Ford; Williams 1989, 380) that are smaller hollows can also have rock forms at their circumference. Karst features may develop from rock features. Actually, rock cavities develop from rock forms (subcutaneous recesses) and in a similar fashion. Diversely composed, crushed, and stratified rock also decisively influences the origin and shape of rock forms. The properties of the rock often prevail over the factors that shape subcutaneous rock forms. An example: subcutaneous notches occur at long-lasting soil levels but can occur also along horizontal bedding planes.

For rock forms that developed on karst surfaces under soil or sediment, I use the term subcutaneous; a Slovene synonym was applied to all karst and rock forms of this type by Gams (1971). He describes various forms that occurred under the soil on karst surfaces and along finegrained sediments in caves.

Karstologists frequently treat subcutaneous karren and the rock forms on them together. They were presented and named by Bögli (1960). Jennings (1973) divides them to smaller forms occurring with the dissolving of partly or completely covered limestone. In the first group he ranks subcutaneous notches (solution notches), and in the second, deep subcutaneous recesses (solution pipes). Bögli (1981) describes channels that occurred under the soil and names them Rundkarren. Trudgill (1985) defines the importance of the shaping of rock under the soil and also describes subcutaneous recesses (Trudgill 1986). In dividing karren, White $(1988,50)$ singles out those that were covered with soil. Due to the flow of water, rounded channels (rounded runnels) occur, and hollows are the result of flowing water and eroded rock. Ford and Williams (1989) divide rock and karst forms mainly according to shape but also according to origin. They describe small hollows (karren shafts and wells), subcutaneous recesses (solution pits), and channels that also occur under weathered debris. Karren that occur due to water flowing through the soil are also described by Ginès (1990). Karren that occur under the soil, he names subsoil karren and lists subcutaneous forms: hollows (tubes) and recesses (Ginès 1996). The importance of the subcutaneous shaping of rock is also stressed by the researchers of the Lunan stone forest, which they describe as a form of covered or subjacent karst 
(Chen Zhi Ping, Song Linhua, and M.M. Sweeting 1983) and cryptokarst (Maire R., Zhang Shouyue, and Song Shixiong 1991; Sweeting 1995, 125).

I have previously described rock forms linked to the filling of karst caves with fine-grained sediment (Slabe 1995). I divided them into above-sediment and under-sediment rock forms, adding new forms from various caves. These are most frequently composed rock forms shaped by several different factors at the same time.

Rocks are often overgrown or criss-crossed by roots (Jakucs 1977, 137; Ollier 1984, 52). I do not count traces of this kind among subcutaneous rock forms, although vegetation naturally influences the formation of the described subcutaneous rock relief.

In the shaping of rocks under the soil, the importance of water that becomes rich with $\mathrm{CO}_{2}$ during percolation through the soil is significant. Trudgill $(1985,58,68)$ established that water from the soil in most cases has a greater ability to dissolve carbonate rock than water working on a bare surface. The speed of the dissolving depends on the type of the soil and that the properties of the water at the contact with the rock are preserved in order to dissolve the rock. These properties come from the $\mathrm{CO}_{2}$ in the air and the soil and from organic acids (Trudgill 1985, 57).

In this article, my focus is primarily on basic, typical rock forms and the factors creating them. The following findings are extracts from the middle of the research. At the moment, I am focusing much attention to rock forms of this type in my study of the rock relief of the Lunan stone forest (Slabe 1998). Typical subcutaneous rock forms are recesses, channels and notches, but I did not yet include all of their different varieties as, obviously, their number increases during the research. Such a way contributes that the research is more clear and that deepening of knowledge about newly discovered rock forms and their development is faster. I am well aware that this is an experiment. It was difficult to decide whether into this group of rock forms belong also those developed at the surface of the soil or sediment that surround the rock. Compared to other rock forms just this relation with soil or sediments is crucial. The feature, typical of this contact does not develop on the surface only but also below it.

\section{SUBCUTANEOUS ROCK FORMS}

I have divided (see table) rock forms whose origin is linked to the fine-grained sediment and soil that completely or only partly covered the rock during their period of development into those that developed due to the flowing of the water along the contact of sediment and soil with the rock, those that developed under a thinner layer of soil and vegetation when water percolated through the soil, and those that developed along the surface of the soil and are composed and directly formed by water from the surface. However, we must also distinguish between the subcutaneous dismembering of rock that is specifically the consequence of the composition, joint frequency, and stratification of the rock, that is the weak spots in the rock, from subcutaneous rock forms created by characteristic factors. The rock is rounded due to the characteristic dissolving of rock under soil and sediment.

Their surface is smooth if the rock is quite evenly composed. With great enlargement using a scanning electron microscope, we can establish that surface is finely dismembered, the result of the more rapid dissolving of rock along weak spots in the rock, that is, at the contact with the various particles that compose it. More slowly dissolving particles that can protrude distinctly from the rock surface remain on it (Slabe 1994) even though they are subject to faster dissolving due to the 
larger surface area exposed. Roughness, of course, is influenced by the composition and the way the rock has been crushed. Trudgill (1985) measured the roughness of rock surfaces and on the basis of their porosity and the height of protruding fossils and chert established the degree of corrosion of the rock.

Table: Subcutaneous Rock Forms.

\begin{tabular}{|c|c|c|}
\hline \multicolumn{2}{|c|}{ UNDER SOIL AND SEDIMENT } & AT THE LEVEL OF SOIL \\
\hline $\begin{array}{l}\text { water flowing at the contact } \\
\text { of sediment and soil with } \\
\text { the rock }\end{array}$ & $\begin{array}{l}\text { percolation of water through } \\
\text { soil }\end{array}$ & \\
\hline $\begin{array}{l}\text { subcutaneous small and } \\
\text { large channels } \\
\text { subcutaneous scallops }\end{array}$ & $\begin{array}{l}\text { subcutaneous small and } \\
\text { large channels } \\
\text { subcutaneous small and } \\
\text { large recesses }\end{array}$ & $\begin{array}{l}\text { subcutaneous half-bells } \\
\text { subcutaneous notches }\end{array}$ \\
\hline
\end{tabular}

\section{Subcutaneous Channels}

Large vertical channels (Fig. 1) have diameters from twenty centimeters to one meter and more. They develop when larger quantities of water flow continuously along the permeable contact with the rock. The largest channels can be wide and shallow, and along fissures where the channels are most frequent they can also be deep. The size of the diameter of semicircular subcutaneous channels can fluctuate. Deep under the soil and sediment, large channels frequently narrow distinctly. The rock therefore dissolves most rapidly at the upper part of the soil and sediment. Along the most distinct fissures, subcutaneous shafts can occur in the middle of a pillar. I observed the most distinct and varied channels in the Lunan stone forest that developed below Eocene lake sediments and the laterite soil that formed on top of them. Their occurrence is also influenced by the rock on which they are formed. In the Lao Hei Gin stone forest, subcutaneous channels are preserved on the harder stone tops and feet. They are several meters wide and up to half a meter deep and are dissected by subcutaneous recesses. Channels are visible at all heights only on pillars that are close together. The pillars are therefore undercut and overhang considerably. On the upper parts of the pillars, subcutaneous channels are distinct only on lower pillars that have not been denuded long enough for rainwater to reshape them to a larger degree. As a rule, they no longer exist in the denuded middle sections of the pillars due to the fine disintegration of the porous dolomite. Large channels that are more rounded and shallow also dissect the walls of the Naigu stone forest. Smaller rock forms on the dolomite limestone that constitutes the upper parts of the pillars are nonexistent or indistinct due to the composition of the rock or its decay.

Smaller channels (Fig. 2) five to twenty centimeters in diameter criss-cross the wall at various angles and can have winding shapes. They are equally wide along their entire length or wider at the contact with other channels. They can also be linked in a network. Subcutaneous channels also occur in the lower sections of the pillars in the Shilin Central Forest which is composed of layers of 
limestone containing large lenses of chert. There are no smaller rock forms on such rock.

Channels therefore appear under sediment and soil, and when the level of the sediment drops, the denuded parts of the pillars are reshaped by rainwater. Their surface is therefore dissected by small recesses. Below deep channels formed by rainwater on the tops of pillars, their lower parts under overhangs are shallow and wider, only partly reshaped by rainwater.

As a rule, the most winding channels are subcutaneous small ones between one and five centimeters in diameter. Small channels often run obliquely down the walls and curve by as much as $90^{\circ}$. They occur individually or are connected in characteristic rhombohedral grids.

Large and small subcutaneous channels develop mainly through the soaking of the soil and sediment at the permeable contact with the rock and not due to distinct smaller streams, a fact reflected by the network of small channels and their frequent dissection with small horizontal notches. Small tubes up to one centimeter in diameter through which water flows occur only at the bottom of channels. Along the contact with moist soil, the dissolving of the rock is more distinct and longer lasting. The size and the shape of large and small channels are dictated primarily by the permeability of the contact with the soil and the quantity of water flowing over the contact point, along with the composition of the rock. It appears that the less permeable the contact is, the more winding small channels develop. The nature of the contact between the wall and the soil can vary or change in places. Winding small channels can therefore occur on the walls of larger channels. At poorly permeable contact points, subcutaneous channels are the largest along the level of the sediment and soil, while below it they narrow quickly. Gams (1997) also establishes a connection between the growth of underground caverns and the permeability of their fill. In contrast, in old caves without ceilings, the contact between the clay and the wall has not been reshaped in most cases since the period of the fine corrosion of the rock when the moist fine-grained sediment was deposited (Slabe 1996).

In Lunan, unique vertical or horizontal subcutaneous channels (Fig. 3) with semicircular or overturned omega-shaped cross sections appear at the bottom of the cracks between the pillars or teeth where the fissures are wedged out or where the channels (Fig. 4) criss-cross the tops of larger subcutaneous teeth or lead from subcutaneous recesses. They can occur in storeys. Due to the lowering of the level of the soil, the latter are preserved only at the bottoms of the channels and therefore deepened and widened them. Water flowing along permeable contacts with the rock collects at the bottom of cracks and recesses, and the soil therefore preserves its ability to dissolve the rock for a longer period. Rock teeth are quite regularly pointed and rounded in cross section.

On the walls of rocks or stone teeth protruding through the surface there are also vertical funnelshaped notches that can have diameters of more than one meter. On vertical surfaces, these can continue as subcutaneous channels, while they wedge out on more gradual surfaces. They occur due to the uniting of water flowing from the walls and are therefore often the mouth of large subcutaneous channels.

Due to water flow above fine-grained sediment on the lower part of inclined or horizontal flat rock, i.e. along bedding plane or fissures, occur above sediment channel or anastomoses. Their origin is similar to those in caves (Slabe 1995). Such channels occur in sub-soil karren and on basal conglomerate in flysch.

Under a thinner layer of soil, in most cases in the vicinity of large and small subcutaneous recesses, there are, as a rule, gradually sloping channels with semicircular bottoms. They occur 


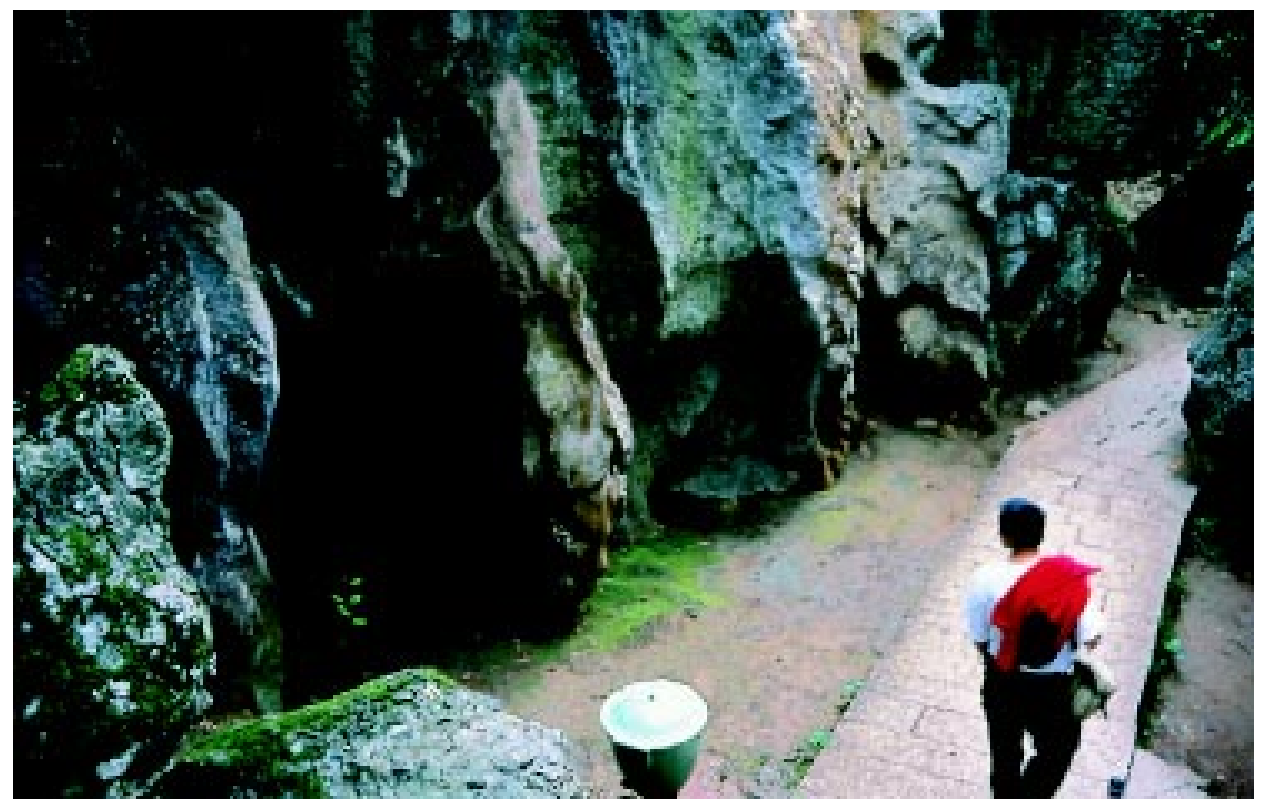

Fig. 1: Large subcutaneous channels.

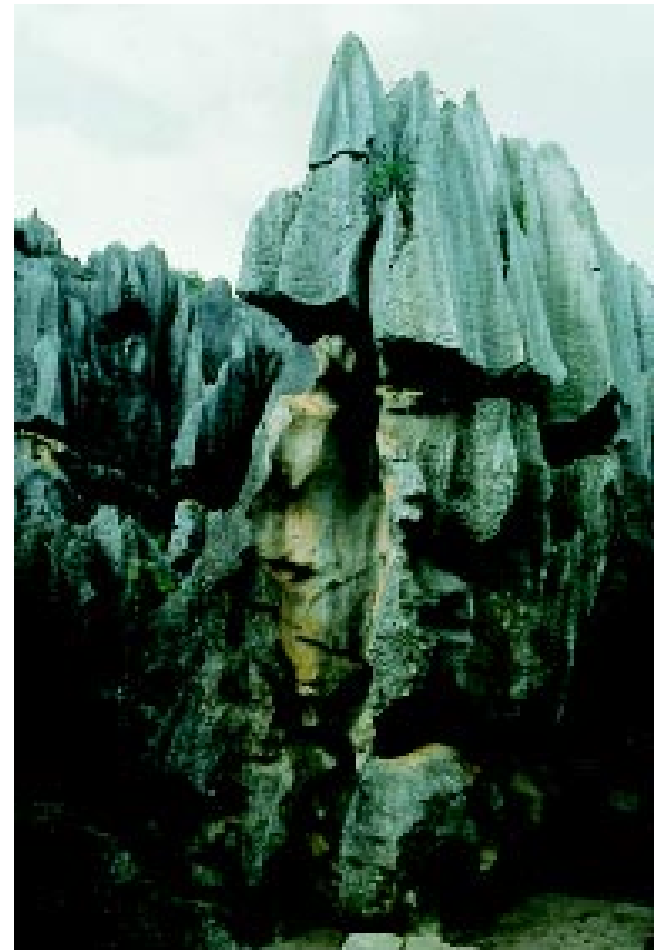

Sl. 1: Veliki podtalni žlebovi.

Fig. 2: Small subcutaneous channel in a large channel.

Sl. 2: Majhen podtalni žleb v velikem. 


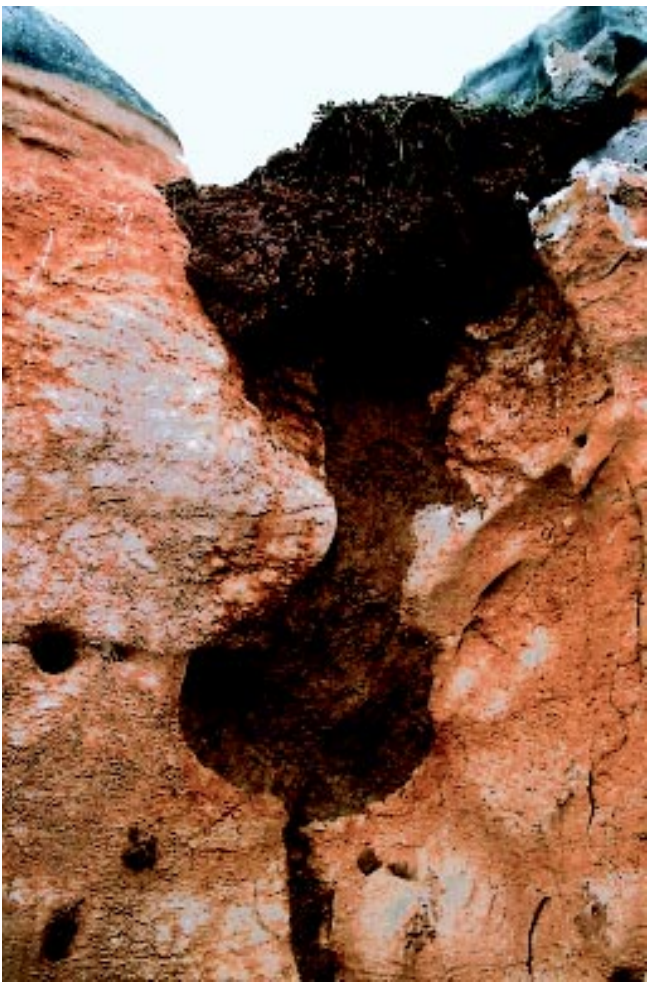

Fig. 3: Subcutaneous channel.

Sl. 3: Podtalni žleb.

Fig. 4: Subcutaneous stone tooth with channels and recess.

Sl. 4: Podtalni kamniti zob s podtalnimi žlebovi.

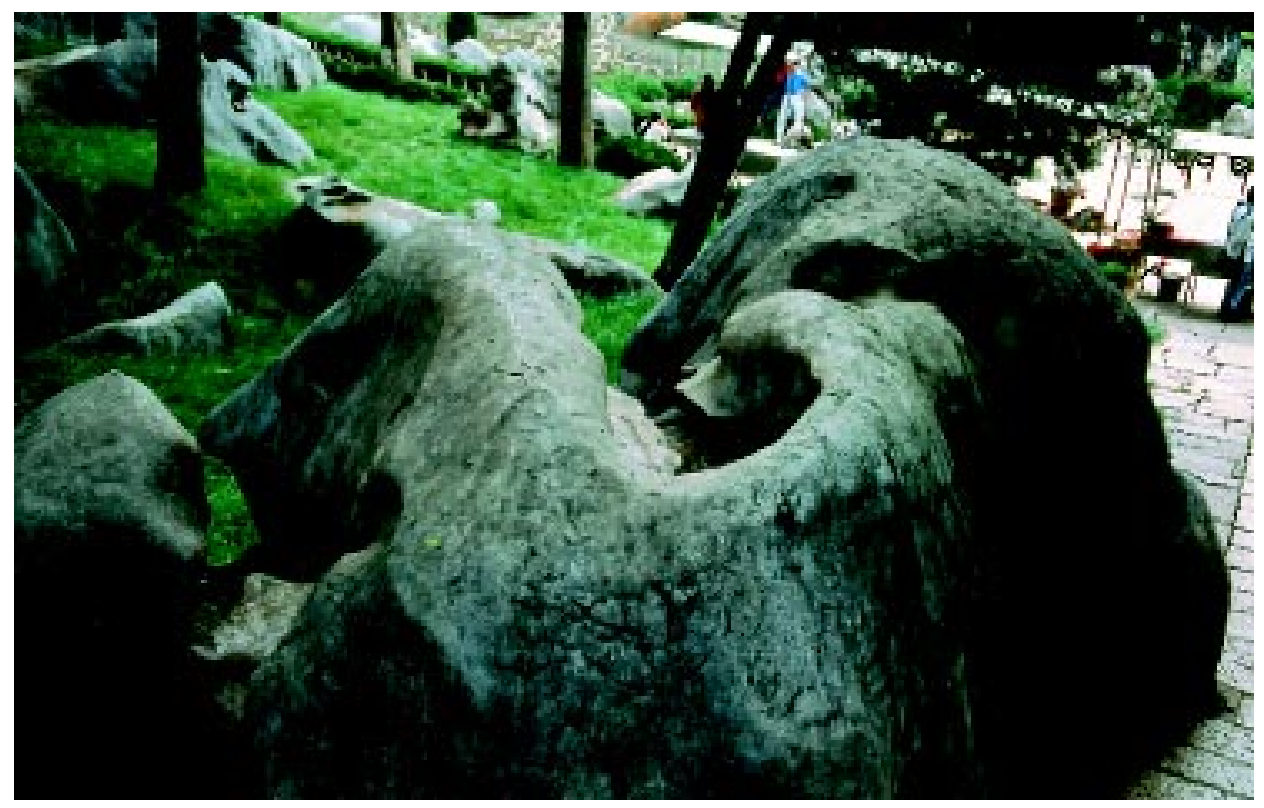


with the accumulation of water that percolated through the soil. Beneath the soil, they also deepen more quickly when only their bottom is covered. On larger rocks, systems of channels developed. Smaller subcutaneous channels unite radially into a larger channel due to the gravitational flow of the water.

There are also unique channels that developed due to water trickling from subcutaneous recesses and solution pans on the tops of the pillars. However, I do not rank them in this group of rock forms. It is necessary to distinguish subcutaneous channels from the subcutaneous channel-like notches that are merely the result of stratification and the way the rock has been crushed.

Subcutaneous channels also occur with the reshaping of rock forms that have been hollowed by rainwater when formerly bare rock is covered by weathered debris or a thick layer of moss.

\section{Subcutaneous Scallops}

Certain subcutaneous recesses ( Fig. 5) are similar to large and open scallops with smooth walls. They are fifteen to fifty centimeters in diameter and are shallow. As a rule, they are found on overhanging rock surfaces $\left(-5^{\circ}\right.$ to $\left.-20^{\circ}\right)$ highly surrounded by soil or sediment. In most cases, they are slightly deeper on the upper side and linked in a network.

Subcutaneous scallops can be observed along distinct fissures along which cracks develop filled with soil. Such scallops as a rule do not occur along fissures criss-crossing the walls or along distinct bedding planes; instead, a semicircular channel develops beside them. It appears that the subcutaneous scallops developed due to the flow of water along the longitudinally permeable contact with the rock and the simultaneous percolation of water through the porous soil and sediment. Along-sediment recesses also occur frequently on the walls of caves filled with fine-grained sediment.

Large recesses are also found on overhanging walls of pillars in the stone forest that have been exposed to rainwater for a longer period. For the moment, I assume that they occurred at the contact with fine-grained sediment. This supposition is supported by the rock dissected by subcutaneous scallops whose yellow surface is rounded and smooth. Such surfaces are most frequently found at the contact with sediment or soil when water trickles from it.

For the moment, I have concluded-though I will attempt to verify my conclusion with experiments in gypsum - that large and small channels occur mainly due to the continuous flow of the water along the more or less permeable contact of rock with less porous sediment and soil while subcutaneous scallops occur along the contact with distinctly porous sediment and soil when a larger quantity of water flows along the contact and simultaneously percolates through the soil and sediment.

\section{Subcutaneous Recesses}

Under a thin layer of porous soil that covers the rock completely or only in places, semicircular small and large recesses (Fig. 6) occur. The former are one to five centimeters in diameter; the latter are larger. They occur due to the percolation of water through the soil to the rock. As a rule, they formed on weak spots in the rock. The water moistens the soil in small recesses and, as a rule, enlarges them in a semicircular fashion when the rock is surrounded by fine-grained sediment or soil. Their cross section is therefore circular or elliptical or rectangular with rounded edges along fissures. The recesses are frequently side by side or are already connected. The previously described subcutaneous channels often lead from them. The subcutaneous teeth in the Lunan stone forests are 
also dismembered in this way. From subcutaneous recesses, a system of the previously mentioned subcutaneous cavities, small hollows, can develop on fissured rock. Trudgill $(1986,468)$ observes that subcutaneous recesses and channels are only found under acidic soils.

From subcutaneous recesses on flat surfaces, solution pans can also occur when the rock is denuded. Their development is presented by Gams (1971, 33), who describes subcutaneous recesses as covered solution pans.

Special subcutaneous recesses develop under newly formed weathered debris. Decaying leaves pile up on the bare rock, maintaining moisture and accelerating the corrosion of the rock. The recesses are at first shallow with gently sloping walls. They range from a few centimeters to several dozen centimeters in diameter. Some have channels that drain excess water. On inclined surfaces, their upper part is semicircular and wide, and they narrow towards the bottom. Below them, subcutaneous channels can start to form, and these also dissect gently sloping sections of various channels on the surface (Jennings 1973, 43).

Deep subcutaneous recesses (solution pipes; Morawiecka 1997) are of special forms and origin. They also develop on hard limestone but are most distinct on soft porous limestone (Ollier 1984,48). Ken Grimes showed me the deep subcutaneous recesses that he is studying in southwestern Australia. Their diameters most frequently reach 0.7 meters, some are wider, and they are several meters deep. Their cross-sections are circular. They occurred on the dune sand from which limestone is formed. Their walls are a solid layer of hardened sand limestone several centimeters thick, and they are filled with soil. On the coast, they are reshaped by sea water. Deep subcutaneous recesses also occur in calcareous gravel (Ollier 1984, 48).

\section{Subcutaneous Notches and Half-bells}

Subcutaneous notches and half-bells develop due to the corrosion of rock along long-lasting levels of sediment and soil that surrounds it. Smaller subcutaneous notches, ten to twenty centimeters in diameter, have the form of semicircular horizontal channels, except that their upper edges are sharper and their lower rounded. Hanging notches are often reshaped by rainwater. Larger subcutaneous notches (Fig. 7) (undercut notches-Waltham 1984, 182; Ford, Salomon, Williams, 1997; solution notches-Jennings 1973, 48; swamp undercut notches-Ollier 1984, 46) are indented a meter and more into the rock, and the largest I have seen in the Lunan stone forest are up to one meter high. The lower part of the notches is undercut, as the rock here has been subjected to faster and longer-lasting dissolving under moist ground and is therefore also rounded and smooth. The bottom of the notch is horizontal, while the upper part lowers toward the bottom in a semicircular fashion. The upper part of the notch has been reshaped due to the trickling of rainwater. Thus, smaller semicircular notches appear first and then grow increasingly larger with the slow lowering of the level of sediment. Notches can be seen at various heights on the rock pillars and rocks at long-lasting levels of soaked soil that dropped intermittently. Smaller and exposed notches are more distinctly reshaped by rainwater than large ones. The water that forms them often flows between the rock and the soil below them to form subcutaneous channels. The forms described are distinguished from notches that occur due to the often faster dissolving of rock along horizontal bedding planes. As a rule, the latter are narrower and in most cases relatively deep in relation to the diameter of the opening.

Subcutaneous half-bells (Fig. 8) occur below channels that lead larger quantities of rainwater 


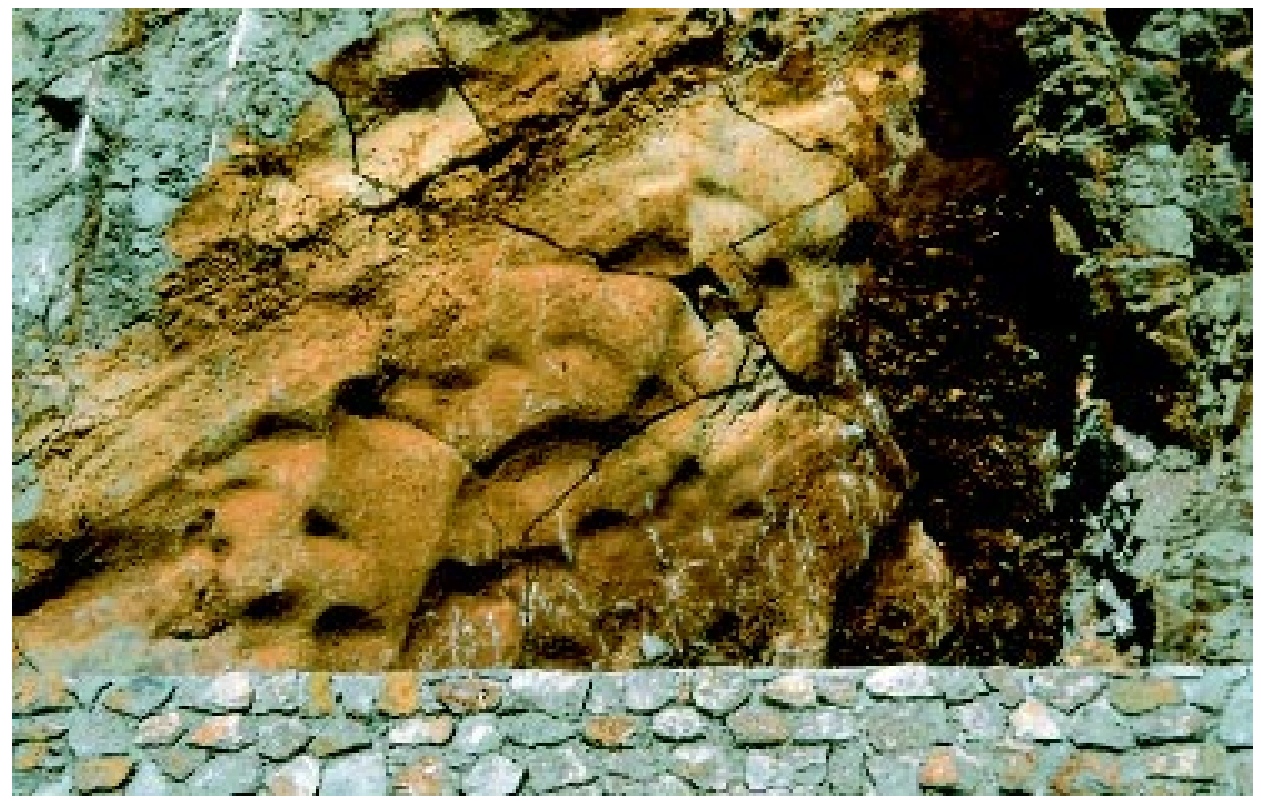

Fig. 5: Subcutaneous scallops.

Sl. 5: Podtalne fasete.

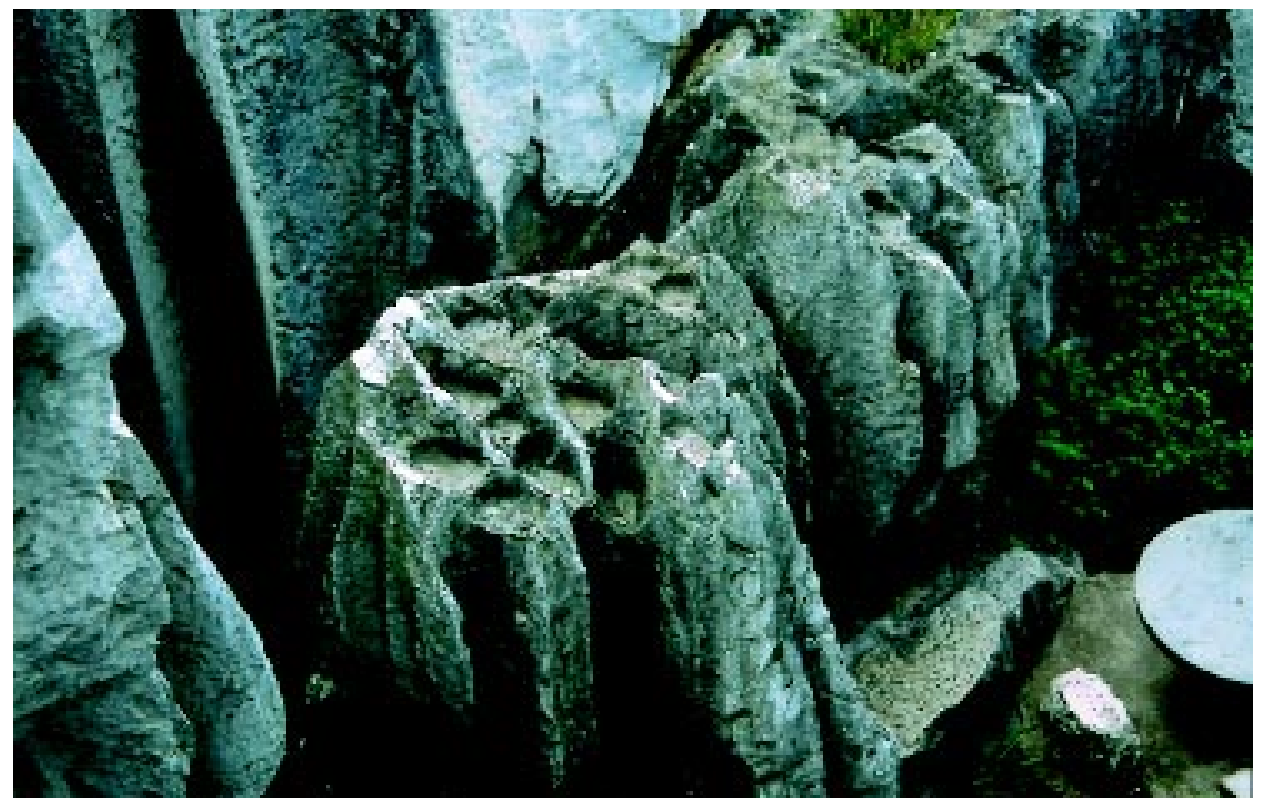

Fig. 6: Subcutaneous recesses.

Sl. 6: Podtalne vdolbine. 

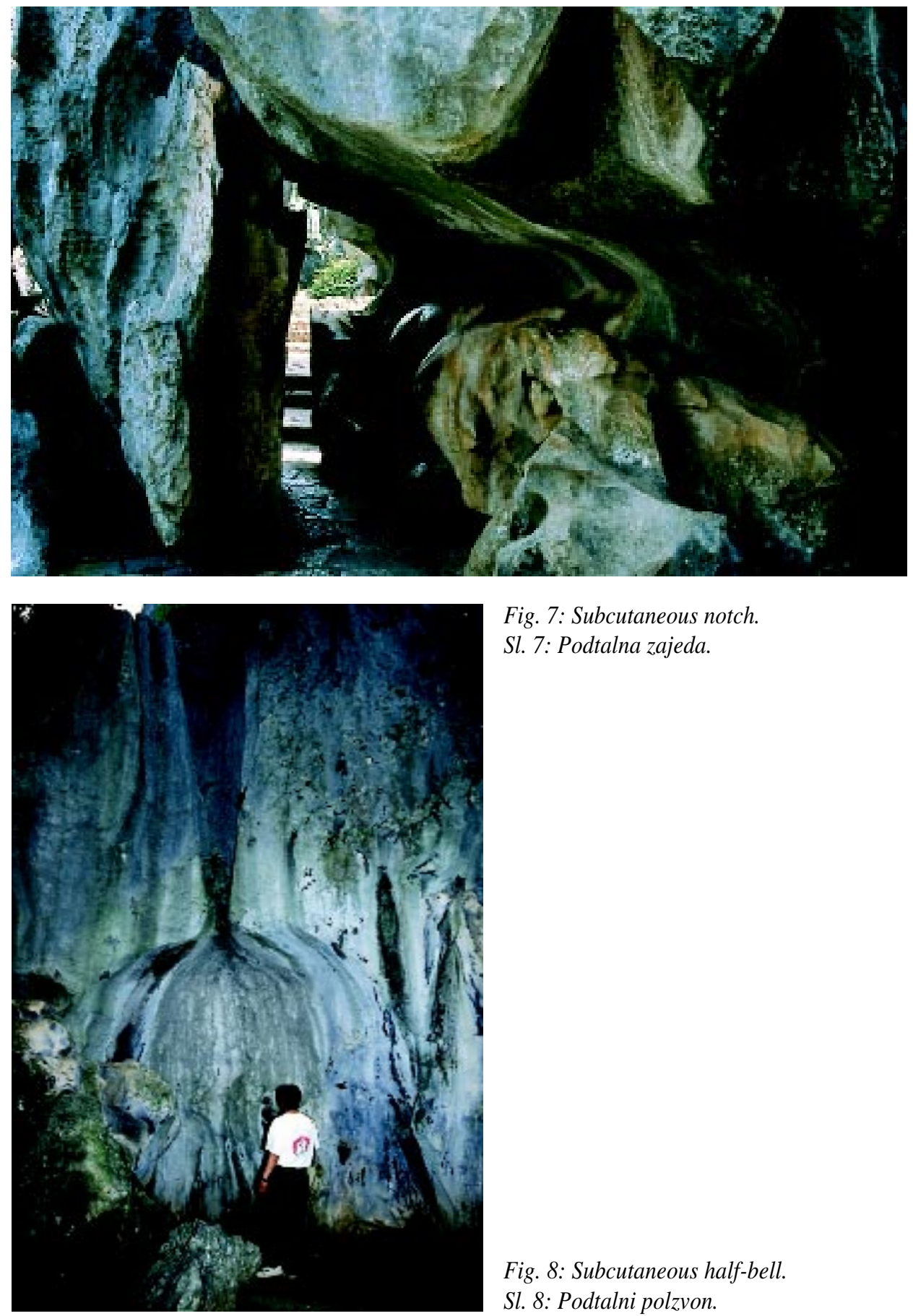

Fig. 7: Subcutaneous notch.

Sl. 7: Podtalna zajeda.

Fig. 8: Subcutaneous half-bell. Sl. 8: Podtalni polzvon. 
trickling down the walls to the sediment. I studied the most distinct and largest ones in the Lunan stone forest. Above the soil and sediment, the expansions have characteristic bell and half-bell forms. Their shape and size are linked to the quantity of the water reaching the soil, the permeability of the contact between the rock and the soil, and the duration of the lowering level of the soil or sediment. When formed along a distinct fissure, the upper part of the channel can also be a tube, and the wall is only weathered at the area of expansion. The walls of bells from which soil was recently removed can be criss-crossed by longitudinal subcutaneous recesses reaching up to a meter in diameter. Large bells also occur between the pillars. The upper parts of half-bells and bells are reshaped by trickling water that gives them their distinctly semicircular form. Lower, under the ground, the bell-shaped expansions usually narrow gradually into subcutaneous channels.

In short, notches and bells occur when more water flows to the contact with the soil or sediment surrounding the rock than the contact or the unevenly porous sediment can immediately conduct and the dissolving of the rock at this spot is therefore more rapid. The poorer permeability of the contact points below notches and subcutaneous bells is also proven by the presence of subcutaneous small channels.

\section{Rock Relief of Subcutaneous Tubes}

Rocks under the ground are often perforated by tubes of various size, in other words, karst caverns that have been filled with sediment or soil during their formation. They are of different sizes and forms. I do not include them among rock forms. The larger ones, however, have rock forms on their circumferences.

Smaller subcutaneous rock cavities (rocky hollows-Gams 1971, 29) with diameters from one to ten centimeters hollow the rock in various directions. The majority developed on distinctly fissured rock. Vegetation often plays an important role in their formation.

The largest tubes I have observed, up to one meter or more wide, are in the Lunan stone forest. They occurred on distinct bedding planes, fissures, or porous rock. The water deposited sediment in the initially small tubes and at the same time widened them. The pillars in the Lao Hei Gin stone forest are perforated by tubes in their middle and lower sections, that is, in layers of distinctly porous dolomite rock, while they are practically non-existent on the tops and at the feet of the pillars. They penetrate deeply into the rock, and some run through the pillars. The bottoms of the semicircular tubes, on top of which are often smaller above-sediment channels, are clayey if they are situated in the layer of sediment and soil. Above-sediment ceiling channels occurred when the level of the subcutaneous tubes was under the soil. The tubes were filled with sediment, above which smaller quantities of water flowed. The size of the tubes, which reach 1.5 meters in diameter, and their branching indicate the long duration of the formation. The majority of subcutaneous tubes in the pillars of the Shilin stone forest are smaller. They occurred along fissures in the middle sections of the pillars. Only individual tubes are larger, reaching up to two meters in diameter. In most cases, their cross section has the shape of a horizontally elongated ellipse. As a rule, there are channels on their bottoms formed when the level of the sediment encircling the pillars dropped and the water flowed only along the bottoms of the channels. In Naigu, large tubes occurred at the contact between the harder and unfissured tops and the lower, thinner layers of rock. In most cases, they are not larger than one meter in diameter, although some are genuine tunnels. 


\section{CONCLUSION}

Subcutaneous rock forms occur on karst surfaces covered with sediment or soil. They are the consequence of water running along the contact between rock and soil, the percolation of water through the soil, and inflow of water to the surface of the soil surrounding the rock. Sediment and soil vary in permeability and composition, which influences the properties of the water at the contact with the rock, and surround the rock with layers of various thickness. Diversely composed, crushed, and stratified rock also decisively influences the origin and shape of rock forms

Subcutaneous rock forms are a distinct sign of the formation of the rock under the ground and are also often an important trace of the development of the karst surface and its use. On larger karren in particular, karstologists have frequently observed many periods in their development. I will cite only a few examples where the rock relief reflects the development of the karst surface.

The changing of rock relief is clearly visible in the Lunan stone forests where on the pillars there are criss-crossing traces of the original shaping of the rock under the soil and sediment, signs of the dropping of the level of soil and sediment, and signs of the younger but distinct reshaping of the pillars by rainwater, which, of course, prevail on the tops. With the development of underground water routes, the water began to carry away the soil and sediment more rapidly from the surface. With the lowering of the level of sediment and soil surrounding the carbonate rock, the original subcutaneous rock forms on the pillars of the stone forest were reshaped into rock forms hollowed by rainwater, in some places more and in others less efficiently. However, the legacy of subcutaneous rock forms is still visible in the rock relief on the parts of the pillars that have been shaped by rainwater for a long time, for example, the funnel-shaped dismembered tops of the rocks and the large channels.

A similar development of the karren, although of shorter duration and broken into fewer distinct periods, can also be observed around Lipica (Kras, Slovenia). On the denuded but still subcutaneously rounded rock, very small channels formed at first that grew into small channels, and solution pans developed on more gently sloping areas. Uncovered subcutaneous channels were reshaped by rainwater, and on their more gently sloping parts, weathered debris again piled up, beneath which recesses developed. There are subcutaneous rock forms on the lower parts of the rock teeth that compose the karren near Kozina (Kras, Slovenia). These include subcutaneous channels that developed due to the flowing of water from the surface along the contact between the rock and the soil and notches that developed at long-lasting soil levels. The upper parts of the teeth are crisscrossed by rock forms (small channels, solution pans) hollowed by rainwater. These subsequently reshaped the subcutaneous rock forms as the level of the soil dropped. The karst surface was finely dismembered, and rocks covered by weathered debris were increasingly denuded and exposed to the climatic influences. Water washed the soil from the permeable surface. This was also a consequence of the use of the karst surface and the clearing of forest. With the rapid overgrowth that is the consequence of the abandoning of pastures, the course of development is again changing. Below the dense tree and bush vegetation, the rocks are again being covered, first by moss and then by weathered debris. The re-covering of the rocks by soil was described by Trudgill $(1985,67)$. In some places, rock forms hollowed by rainwater are already being reshaped under a thin layer of vegetation.

The aim of this presentation of subcutaneous rock forms is to supplement the knowledge of the 
shaping of carbonate rock below the ground under various conditions and is an attempt to unify the diverse definitions, descriptions, and denominations of rock forms. Further study and comparison of various rock relief will deepen our understanding of the development of the karst surface.

\section{REFERENCES}

Bögli, A., 1960: Kalklösung und Karrenbildung.- Intern. Beiträge zur Karstmorphologie, Z.f. Geomorphologie, Supp. 2.

Bögli, A., 1981: Solution of limestone and karren formation.- Karst geomorphology, Ed. M.M. Sweeting, Benchark Papers in Geology 59, 64-89, Hutchinson Ross Publishing Company.

Chen Zhi Ping, Song Lin Hua and M.M. Sweeting, 1983: The Pinacle Karst of the Stone Forest, Lunan, Yunnan, China: an example of sub-jacent karst.- New Direction in Karst, Proceedings of the Anglo-French Karst Symposium, Edited by K. Paterson and M.M. Sweeting.

Ford, D., P. Williams, 1989: Karst Geomorphology and Hidrology.- U. Hyman, p.601, London.

Ford, D., J.N. Salomon, P. Williams, 1997: The Lunan Stone forest as a potential world heritage site.- Stone forest a treasure of natural heritage, Proceedings of International Symposium for Lunan Shilin to Apply for World Natural Heritage Status, 107-123, China environmental science press.

Gams. I. 1971: Podtalne kraške oblike.- Geografski vestnik 43, 27-45, Ljubljana.

Gams, I., 1997: Climatic and lithological influence on the cave depth development.- Acta carsologica 26/2, 321-336, Ljubljana.

Ginés, A., 1990: Utilización de las morfologías de lapiaz como geoindicadones ecológicas en la Serra de Tramuntana (Malorca).- Endins 16, 27-39, Palma de Mallorca.

Ginés, A., 1996: An environmental approach to the typology of karren landform assemblages in a Mediterranean mid-mountain karst: the Serra de Tramuntana, Mallorca, Spain.- Karren landforms, edited by J.J. Fornós, A. Ginés, 163-176, Palma.

Jakucs, L., 1977: Morphogenetics of karst regions.- Akadémiai Kiadó, pp.284, Budapest.

Jennings J.N., 1973: Karst.- The M.I.T. Press, Cambridge, Massachusetts and London, England, pp. 253.

Maire, R., Zhang Shouyue, Song Shixiong, 1991: Genese des karsts subtropicaux de Chine du sud (Guizhou, Sichuan, Hubei).- Gebihe 89, Grottes et karsts tropicaux de Chine Meridionale, Karstologia memoires $\mathrm{N}^{0} 4,162-186$.

Morawiecka, I., 1997: Piping karst in the pleistocene raised beaches of south-west England and south Wales.- Wydawnictwo Uniwersytetu Śląskiego, p.112, Katowice.

Ollier, C., 1984: Weathering.- Longman, pp.270, London and New York.

Sweeting, M.M, 1995: Karst in China.- Springer-Verlag, p.p. 265, Berlin, Heidelberg, New York.

Slabe, T., 1994: Dejavniki oblikovanja jamske skalne površine.- Acta carsologica 23, 369-398, Ljubljana.

Slabe, T., 1995: Cave Rocky Relief and its Spelogenetical Significance.- ZRC 10, pp. 128, Ljubljana.

Slabe, T. 1996: Karst features in the motorway section beetwen Čebulovica and Dane.- Acta carsologica 13, 221-240, Ljubljana.

Slabe, T., 1998: Rock relief of pillars in the Lunan Stone Forest.- In South China Karst I/Chen Xiaoping et al. Založba ZRC/Ed. Likar, V., 19, 51-67, Ljubljana 
Trudgill; S.T., 1985: Limestone Geomorphology.- Longman, pp.196, London and New York.

Trudgill, S.T., 1986: Limestone weathering under a soil cover and the evolution of limestone pavements, Malham district, north Yorkshire, UK.- New direction in Karst, Proceedings of the Anglo-french Karst symposium, 461-471.

Waltham, A.C., 1984: Some features of karst geomorphology in south China.- Cave science, The Transaction of teh British Cave Research Association, 11, 185-199.

White, W.B., 1988: Geomorphology and Hydrology of Karst Terrains.- Oxford University Press, p.464, New York.

\section{PODTALNE SKALNE OBLIKE}

\section{Povzetek}

Svojevrstne skalne oblike nastajajo tudi na stiku z drobnozrnato naplavino ali prstjo, ki obdajata karbonatne kamnine, bodisi na kraškem površju ali pa v jamah. Ob stiku z njima se pretakajo manjši vodni tokovi in nastajajo različni žlebovi in podtalne fasete, ko pa voda prenika skozi prst, ali pa skozi skalo na stik z njo, nastanejo podtalne vdolbine in žlebovi. Na nivojih prsti nastajajo zajede in polzvonovi. Prerezi tovrstnih skalnih oblik so praviloma polkrožnih in zaobljenih oblik, njihova površina pa gladka. O nastanku skalnih oblik in njihovi podobi ter površini pa soodloča kamnina s svojo sestavo, skladovitostjo in pretrtostjo.

Tabela: Podtalne skalne oblike.

\begin{tabular}{|l|l|l|}
\hline \multicolumn{2}{|c|}{ POD PRSTJO IN NAPLAVINO } & $\begin{array}{l}\text { NA NIVOJU PRSTI IN } \\
\text { NAPLAVINE }\end{array}$ \\
\hline $\begin{array}{l}\text { pretakanje vode na stiku s } \\
\text { prstjo ali naplavino in skalo }\end{array}$ & prenikanje vode skozi prst & \\
\cline { 1 - 2 } podtalni žlebovi in žlebiči & podtalni žlebovi in žlebiči & $\begin{array}{l}\text { podtalni polzvonovi } \\
\text { podtalne zajede }\end{array}$ \\
\hline & $\begin{array}{l}\text { podtalne vdolbine in } \\
\text { vdolbinice }\end{array}$ & \\
\hline
\end{tabular}

Skalne oblike so oblike na skali. Skalni relief, ki jih združuje, je oblika plašča skale ali kraške votline. Skalne oblike so pomembna sled dejavnika, ki je skalo oblikoval. Pogosto se na skali prepletajo sledi več različnih dejavnikov, ki delujejo nanjo hkrati ali pa se razvrstijo v različnih razvojnih obdobjih in mlajše sledi bolj ali manj učinkovito prekrivajo sledi starejših. Skalne oblike ločim od kraških, bodisi škrapelj bodisi vrtač, ki so tudi lahko prekrite s prstjo. Tudi skalne luknje (Gams 1971, 29; Ford; Williams 1989, 380), ki so manjše votline, imajo lahko skalne oblike na obodu. Resda pa skalne luknje nastanejo iz skalnih oblik (podtalnih vdolbin) ali pa podobno kot 
one (podtalni žlebovi). Na nastanek in obliko skalnih oblik odločilno vpliva tudi različno sestavljena, pretrta in skladovita kamnina. Lastnosti kamnine pogosto prevladajo nad dejavniki, ki oblikuje podtalne skalne oblike. Kot primer: podtalne zajede nastanejo na dolgotrajnem nivoju prsti, zajede pa lahko nastanejo tudi ob vodoravnih lezikah.

Skalne oblike, ki so nastale na kraškem površju pod prstjo ali naplavino imenujem podtalne, torej izraz, ki ga je za vse tovrstne kraške oblike nazorno uporabil Gams (1971). Opisuje različne oblike, ki so nastale pod prstjo na kraškem površju in ob drobnozrnati naplavini v jamah.

Podtalne skalne oblike so razločen znak oblikovanja skale pod tlemi in pogosto tudi pomembna sled razvoja kraškega površja in njegove izrabe. Zlasti na večjih škrapljah so krasoslovci pogosto razbirali več obdobij njihovega razvoja. Naj navedem le nekaj primerov, ko skalni relief odseva razvoj kraškega površja.

Spreminjanje skalnega reliefa je jasno razvidno v lunanskih kamnitih gozdovih, kjer so na stebrih prepletene sledi prvotnega oblikovanja skale pod prstjo in naplavino, znaki nižanja nivoja le teh in mlajšega, a izrazitega preoblikovanja stebrov z deževnico, ki seveda prevladujejo na vrhovih. Z razvojem podzemeljskih vodnih poti je voda začela hitreje odnašati prst in naplavino s površja. Z nižanjem nivoja naplavine in prsti, ki obdaja karbonatne kamnine, se torej sprva podtalni skalni relief stebrov kamnitega gozda ponekod bolj, drugod manj učinkovito preoblikuje v skalne oblike, ki jih dolbe deževnica. Toda, tudi v obliki delov stebrov, ki jih že dlje časa oblikuje deževnica, je še dediščina podtalnega skalnega reliefa. Takšni so tudi lijakasto razčlenjeni vrhovi skal in veliki žlebovi.

Podoben, le bolj kratkotrajen in z manj različnimi obdobji razčlenjen razvoj škrapelj lahko opazujemo tudi v Lipici (Kras, Slovenija). Na razgaljeni, a še podtalno zaobljeni skali se sprva oblikujejo majhni žlebiči, ki preraščajo v žlebiče, na položnejših delih skale pa se razvijajo škavnice. Razkrite podtalne žlebove preoblikuje deževnica, na njihovih položnejših delih se spet kopiči preperelina, pod katero nastajajo vdolbine.

Na spodnjih delih skalnih zob, ki sestavljajo škraplje pri Kozini (Kras, Slovenija), so podtalne skalne oblike. To so podtalni žlebovi, ki so nastali zaradi zatekanja vode s površja po stiku skale in prsti, in zajede, ki so nastale na dolgotrajnih nivojih prsti. Zgornji deli zob pa so razčlenjeni s skalnimi oblikami (žlebiči, škavnice), ki jih dolbe deževnica. Te so torej preoblikovale podtalni skalni relief, saj se je nivo prsti nižal. Kraško površje se je v drobnem razčlenjevalo, skale, ki jih je prekrivala preperelina so bile vse bolj razgaljene in izpostavljene podnebnim vplivom. Voda je namreč s prepustnega površja odnašala prst. To je bila tudi posledica izrabe kraškega površja in krčenja gozdov. S hitrim zaraščanjem, ki je posledica človekovega opuščanja pašniških površin, pa se potek njegovega razvoja zopet spreminja. Pod gostim drevesnim in grmičastim rastjem se skale spet pokrivajo najprej z mahom in nato s preperelino. Prekrivanje skal s prstjo je opisal Trudgill (1985, 67). Skalne oblike, ki jih je izdolbla deževnica, so ponekod že preoblikovane pod tanko plastjo rastja.

Tokratna predstavitev podtalnih skalnih oblik ima namen dopolniti spoznanja o oblikovanosti karbonatnih kamnin pod tlemi v različnih razmerah in je poskus poenotenja raznovrstnih opredelitev skalnih oblik, njihovih opisov in poimenovanj. Nadaljnji študij in primerjava različnih skalnih reliefov bo poglabljala predstavo o razvoju kraškega površja. 